\title{
Chronic inflammatory demyelinating polyneuropathy associated with contactin-1 antibodies in a child
}

Laura Carrera-García, MD, Daniel Natera-de Benito, MD, PhD, Cinta Lleixà, PhD, Carlos Ortez, MD, Jaume Colomer, MD, PhD, Andrés Nascimento, MD, Albert Saiz, MD, PhD, Josep Dalmau, MD, PhD, Luis Querol, MD, PhD, and Thaís Armangué, MD, PhD

Neurol Neuroimmunol Neuroinflamm 2019;6:e602. doi:10.1212/NXI.0000000000000602

\author{
Correspondence \\ Dr. Armangué \\ tarmangue@ \\ sjdhospitalbarcelona.org
}

\section{Clinical case}

A previously healthy 2-year and 9-month old boy was brought to the emergency department for a 6-day history of weakness in the legs and frequent falls, rendering him unable to walk 1 day before admission. He did not have pain, dysphagia, bladder dysfunction, or sensory symptoms. There was no history of trauma, but he developed diarrhea 3 days before symptom onset. Family history was negative for consanguinity or neurologic diseases. At examination, he had bilateral leg weakness requiring substantial aid to walk a few steps and was unable to stand up from the floor. He had absent tendon reflexes in the lower extremities and flexor plantar responses. Strength and reflexes in upper extremities and the rest of the examination were normal. CSF showed a protein concentration of $125 \mathrm{mg} / \mathrm{dL}$ (NR: 15-45), with normal white blood cell count and glucose concentration. Blood cell count and chemistry were normal, and stool culture was negative. Nerve conduction studies (NCSs) and EMG showed decreased amplitudes in both peroneal nerves (table e-1, links.lww.com/NXI/A131). The patient was treated with IV immunoglobulins (IVIg) $2 \mathrm{~g} / \mathrm{kg}$ administered in 3 days. During the next 2 weeks, there was mild improvement in motor strength as he was able to walk and stand up with support (the Guillain-Barré syndrome disability scale [GBSds $]^{1}$ score remained 3), and he was discharged home. Two weeks later (4 weeks after symptom onset), he was brought back for worsening weakness in the legs and new onset weakness in the arms. This time, the examination revealed weakness in legs and arms, generalized areflexia, and impossibility to stand up from the floor (GBSds 4). Repeat CSF studies showed a protein concentration of $148 \mathrm{mg} / \mathrm{dL}$ and normal white blood cell count and glucose level. No toxic or infectious etiologies were identified, and serum was negative for ganglioside antibodies. NCSs showed prolonged distal motor latencies, conduction slowing, and decreased amplitude of compound muscle action potentials, along with EMG features of chronic denervation, fibrillation, and positive sharp waves (table e-1, links.lww.com/NXI/A131). Treatment with IVIg was ineffective, but IV methylprednisolone $(30 \mathrm{mg} / \mathrm{kg} / \mathrm{d}$ for 5 days) resulted in substantial improvement, leaving the patient with normal strength except for mild distal lower extremity weakness (GBSds 1).

One year later, after an episode of diarrhea, the patient developed similar clinical and electrophysiologic abnormalities confined to the lower extremities (GBSds 3) fulfilling clinical and electrophysiologic criteria for chronic inflammatory demyelinating polyneuropathy (CIDP). This time, the symptom recrudescence improved with IVIg, and he returned to his baseline (GBSds 1).

From the Neuromuscular Unit (L.C.-G., D.N.B., C.O., J.C., A.N.), Neurology Service, Research Institute, Sant Joan de Deu Children's Hospital, University of Barcelona; Neuromuscular Diseases Unit (C.L., L.Q.), Neurology Department, Hospital de la Santa Creu i Sant Pau, Universitat Autónoma de Barcelona; Centro Investigación Biomédica en Red para Enfermedades Raras (CIBERER) (C.L., J.D., L.Q., T.A.), Madrid; Neuroimmunology Program (A.S., J.D., T.A.), Institut d'Investigació Biomèdica August Pi i Sunyer (IDIBAPS)-Hospital Clínic, University of Barcelona; Catalan Institution for Research and Advanced Studies (ICREA) (.D.), Barcelona, Spain; Department of Neurology (.D.), University of Pennsylvania, Philadelphia; and Pediatric Neuroimmunology Unit (T.A.), Sant Joan de Deu Children's Hospital, University of Barcelona, Spain.

Go to Neurology.org/NN for full disclosures. Funding information is provided at the end of the article.

The Article Processing Charge was funded by the AGAUR.

This is an open access article distributed under the terms of the Creative Commons Attribution-NonCommercial-NoDerivatives License 4.0 (CC BY-NC-ND), which permits downloading and sharing the work provided it is properly cited. The work cannot be changed in any way or used commercially without permission from the journal. 

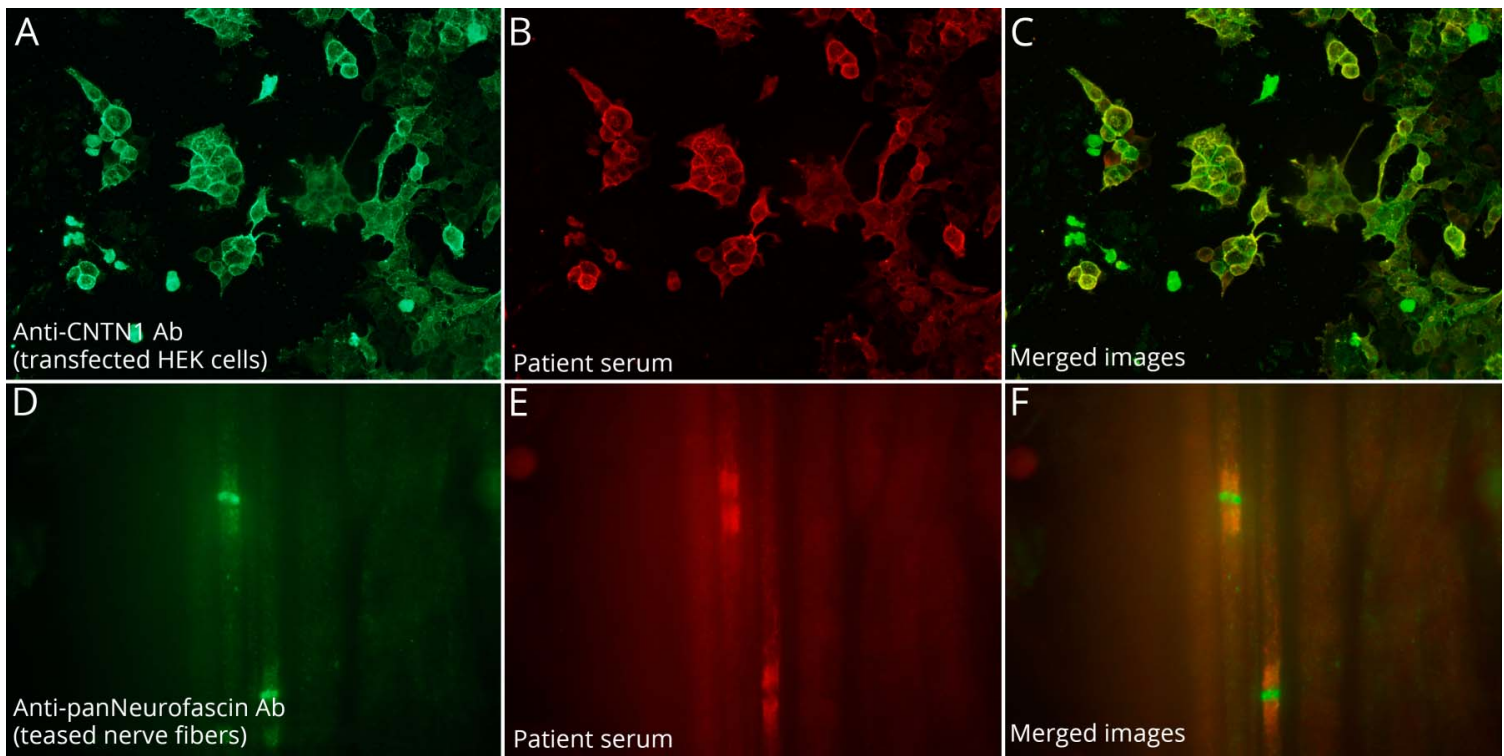

The presence of anti-contactin-1 antibodies was confirmed with contactin-1-transfected human embrionic kidney (HEK) 293 cells. Patient serum (B) showed strong reactivity against contactin-1 and colocalized with the reactivity of a commercial antibody (A) in merged images (C). Patient serum showed strong reactivity against the paranode on pig teased nerve fibers (E) and colocalized with the reactivity of a commercial antibody (D) in merged images (F).

A recent follow-up, 5 years after symptom onset, showed that the neurologic deficits were stable, and the patient had not had further relapses. Current serum studies for antibodies against components of the nodal and paranodal regions of peripheral nerves were negative, but analysis of archived serum and CSF samples obtained at disease onset ( 5 years earlier) showed intense reactivity with teased nerve fibers from pig and human embrionic kidney (HEK) 293 cells expressing contactin-1 demonstrating the presence of these antibodies in both assays (figure).

\section{Discussion}

CIDP is a rare, disabling and treatable disease in children. Antibodies against proteins of the paranode and node of Ranvier (contactin-1, contactin-associated protein 1, and neurofascin 155 and 186) have been recently described in several subsets of patients with CIDP. ${ }^{2}$ In particular, CIDP associated with antibodies against the 155 isoform of neurofascin develop at younger ages, including pediatric patients. ${ }^{2,3}$ However, antibodies against contactin-1 have never been reported in children. These antibodies are predominantly IgG4 subclass and associate with a form of CIDP that manifests with an aggressive symptom onset, resembling GuillainBarré syndrome, with predominant motor weakness, ataxia, and absent or limited response to IVIg or steroids but an excellent response to rituximab. ${ }^{4,5}$ This disorder represents approximately $2 \%-4 \%$ of all patients with CIDP. Clinical improvement is usually accompanied by a decrease of contactin-1 antibody titers. ${ }^{6,7}$ Our patient had a similar presentation with predominant motor involvement and NCSs and EMG suggesting demyelinating features accompanied by early axonal damage. However, he had a less aggressive course compared with that described in adults. Because at the last follow-up, 5 years after disease onset, the patient's deficits had remained stable for 4 years, treatment with rituximab was not considered. It is likely that an earlier recognition of the disorder, by examining contactin-1 antibodies at disease onset, would have prompted treatment with rituximab and perhaps prevented some of his deficits.

Experience with this patient indicates that contactin-1 antibody-associated CIDP can occur in children. Testing for antibodies against nodo-paranodal proteins is important in pediatric patients with CIDP refractory to conventional therapies because antibody findings can help optimizing their care.

\section{Study funding}

This study was supported in part by Instituto Carlos III/FEDER (FIS 17/00234 (J.D.), FIS16/00627 (L.Q.), CM17/00054 (D.N.)); CIBERER \#CB15/00010 (T.A., J.D., L.Q.); AGAUR (Generalitat de Catalunya); Pla estratègic de recerca i innovació en salut (PERIS), Departament de Salut, Generalitat de Catalunya (SLT006/17/00131, L.Q.); and Fundació CELLEX (J.D.).

\section{Disclosure}

J. Dalmau receives royalties from Athena Diagnostics for the use of Ma-2 as an autoantibody test and from Euroimmun AG for the use of NMDA, GABAB receptor, GABAA receptor, DPPX, and IgLON5 as autoantibody tests and is Editor of Neurology: Neuroimmunology \& Neuroinflammation. The other authors report no relevant disclosures. Go to Neurology.org/NN for full disclosures. 


\section{Publication history}

Received by Neurology: Neuroimmunology \& Neuroinflammation April 12, 2019. Accepted in final form June 25, 2019.

\section{Appendix Authors}

\begin{tabular}{|c|c|c|c|}
\hline Name & Location & Role & Contribution \\
\hline $\begin{array}{l}\text { Laura } \\
\text { Carrera } \\
\text { García, MD }\end{array}$ & $\begin{array}{l}\text { Sant Joan de Déu } \\
\text { Children's Hospital }\end{array}$ & Author & $\begin{array}{l}\text { Data collection; } \\
\text { interpreted the data; } \\
\text { follows the patient; } \\
\text { and writing/drafting } \\
\text { the initial manuscript }\end{array}$ \\
\hline $\begin{array}{l}\text { Daniel } \\
\text { Natera-de } \\
\text { Benito, MD, } \\
\text { PhD }\end{array}$ & $\begin{array}{l}\text { Sant Joan de Déu } \\
\text { Children's Hospital }\end{array}$ & Author & $\begin{array}{l}\text { Interpreted the data; } \\
\text { follows the patient; } \\
\text { and critically reviewed } \\
\text { and revised the } \\
\text { manuscript }\end{array}$ \\
\hline $\begin{array}{l}\text { Cinta Lleixà, } \\
\text { PhD }\end{array}$ & $\begin{array}{l}\text { Hospital de la Santa } \\
\text { Creu i Sant Pau }\end{array}$ & Author & $\begin{array}{l}\text { Performed the } \\
\text { neuroimmunologic } \\
\text { studies; analyzed the } \\
\text { data; and developed } \\
\text { the figures }\end{array}$ \\
\hline $\begin{array}{l}\text { Carlos Ortez, } \\
\text { MD }\end{array}$ & $\begin{array}{l}\text { Sant Joan de Déu } \\
\text { Children's Hospital }\end{array}$ & Author & $\begin{array}{l}\text { Interpreted the data; } \\
\text { follows the patient; } \\
\text { and critically reviewed } \\
\text { and revised the } \\
\text { manuscript }\end{array}$ \\
\hline $\begin{array}{l}\text { Jaume } \\
\text { Colomer, } \\
\text { MD, PhD }\end{array}$ & $\begin{array}{l}\text { Sant Joan de Déu } \\
\text { Children's Hospital }\end{array}$ & Author & $\begin{array}{l}\text { Interpreted the data; } \\
\text { follows the patient; } \\
\text { and critically reviewed } \\
\text { and revised the } \\
\text { manuscript }\end{array}$ \\
\hline $\begin{array}{l}\text { Andrés } \\
\text { Nascimento, } \\
\text { MD }\end{array}$ & $\begin{array}{l}\text { Sant Joan de Déu } \\
\text { Children's Hospital }\end{array}$ & Author & $\begin{array}{l}\text { Interpreted the data; } \\
\text { follows the patient; } \\
\text { and critically reviewed } \\
\text { and revised the } \\
\text { manuscript }\end{array}$ \\
\hline $\begin{array}{l}\text { Albert Saiz, } \\
\text { MD, PhD }\end{array}$ & $\begin{array}{l}\text { IDIBAPS and } \\
\text { Hospital Clinic }\end{array}$ & Author & $\begin{array}{l}\text { Performed the } \\
\text { neuroimmunologic } \\
\text { studies; and analyzed } \\
\text { the data }\end{array}$ \\
\hline
\end{tabular}

Appendix (continued)

\begin{tabular}{|c|c|c|c|}
\hline Name & Location & Role & Contribution \\
\hline $\begin{array}{l}\text { Josep } \\
\text { Dalmau, MD, } \\
\text { PhD }\end{array}$ & $\begin{array}{l}\text { University of } \\
\text { Pennsylvania, } \\
\text { IDIBAPS and } \\
\text { Hospital Clinic }\end{array}$ & Author & $\begin{array}{l}\text { Coordinated and } \\
\text { supervised data } \\
\text { collection and critically } \\
\text { reviewed and revised } \\
\text { the manuscript }\end{array}$ \\
\hline $\begin{array}{l}\text { Luis Querol, } \\
\text { MD, PhD }\end{array}$ & $\begin{array}{l}\text { Hospital de la Santa } \\
\text { Creu i Sant Pau }\end{array}$ & Author & $\begin{array}{l}\text { Coordinated and } \\
\text { supervised data } \\
\text { collection and critically } \\
\text { reviewed and revised } \\
\text { the manuscript }\end{array}$ \\
\hline $\begin{array}{l}\text { Thaís } \\
\text { Armangué, } \\
\text { MD, PhD }\end{array}$ & $\begin{array}{l}\text { Sant Joan de Déu } \\
\text { Children's Hospital, } \\
\text { IDIBAPS and } \\
\text { Hospital Clinic }\end{array}$ & Author & $\begin{array}{l}\text { Designed and } \\
\text { conceptualized the } \\
\text { study; performed the } \\
\text { neuroimmunologic } \\
\text { studies; analyzed the } \\
\text { data; follows the } \\
\text { patient; drafted the } \\
\text { manuscript; and } \\
\text { developed the figures }\end{array}$ \\
\hline
\end{tabular}

\section{References}

1. Hughes RA, Newsom-Davis JM, Perkin GD, Pierce JM. Controlled trial prednisolone in acute polyneuropathy. Lancet 1978;2:750-753.

2. Querol L, Devaux J, Rojas-Garcia R, Illa I. Autoantibodies in chronic inflammatory neuropathies: diagnostic and therapeutic implications. Nat Rev Neurol 2017;13: 533-547.

3. Vural A, Doppler K, Meinl E. Autoantibodies against the node of ranvier in seropositive chronic inflammatory demyelinating polyneuropathy: diagnostic, pathogenic, and therapeutic relevance. Front Immunol 2018;14:1029.

4. Querol L, Nogales-Gadea G, Rojas-Garcia R, et al. Antibodies to contactin-1 in chronic inflammatory demyelinating polyneuropathy. Ann Neurol 2013;73: 370-380.

5. Miura Y, Devaux JJ, Fukami Y, et al. Contactin 1 IgG4 associates to chronic inflammatory demyelinating polyneuropathy with sensory ataxia. Brain 2015;138: 1484-1491.

6. Querol L, Rojas-García R, Diaz-Manera J, et al. Rituximab in treatment-resistant CIDP with antibodies against paranodal proteins. Neurol Neuroimmunol Neuroinflamm 2015;2:e149. doi:10.1212/NXI.0000000000000149.

7. Doppler K, Appeltshauser L, Wilhelmi K, et al. Destruction of paranodal architecture in inflammatory neuropathy with anti-contactin-1 autoantibodies. J Neurol Neurosurg Psychiatry 2015;86:720-728. 


\section{Neurology ${ }^{\oplus}$ \\ Neuroimmunology \& Neuroinflammation}

Chronic inflammatory demyelinating polyneuropathy associated with contactin-1 antibodies in a child

Laura Carrera-García, Daniel Natera-de Benito, Cinta Lleixà, et al.

Neurol Neuroimmunol Neuroinflamm 2019;6;

DOI 10.1212/NXI.0000000000000602

This information is current as of July 24, 2019

Neurol Neuroimmunol Neuroinflamm is an official journal of the American Academy of Neurology.

Published since April 2014, it is an open-access, online-only, continuous publication journal. Copyright

Copyright $\odot 2019$ The Author(s). Published by Wolters Kluwer Health, Inc. on behalf of the American

Academy of Neurology.. All rights reserved. Online ISSN: 2332-7812.

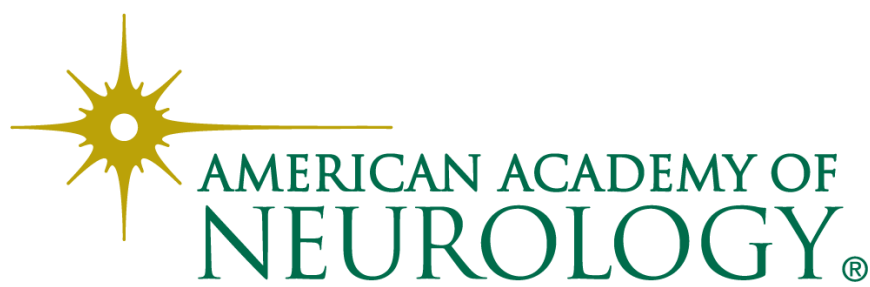




\section{Updated Information \& Services}

References

Citations

Subspecialty Collections

Permissions \& Licensing

Reprints including high resolution figures, can be found at:

http://nn.neurology.org/content/6/5/e602.full.html

This article cites 7 articles, 1 of which you can access for free at: http://nn.neurology.org/content/6/5/e602.full.html\#\#ref-list-1

This article has been cited by 1 HighWire-hosted articles: http://nn.neurology.org/content/6/5/e602.full.html\#\#otherarticles

This article, along with others on similar topics, appears in the following collection(s):

\section{All Pediatric}

http://nn.neurology.org//cgi/collection/all_pediatric

Chronic inflammatory demyelinating polyneuropathy

http://nn.neurology.org//cgi/collection/chronic_inflammatory_demyeli nating_polyneuropathy

EMG

http://nn.neurology.org//cgi/collection/emg

Guillain-Barre syndrome

http://nn.neurology.org//cgi/collection/guillainbarre_syndrome

Information about reproducing this article in parts (figures,tables) or in its entirety can be found online at:

http://nn.neurology.org/misc/about.xhtml\#permissions

Information about ordering reprints can be found online: http://nn.neurology.org/misc/addir.xhtml\#reprintsus

Neurol Neuroimmunol Neuroinflamm is an official journal of the American Academy of Neurology.

Published since April 2014, it is an open-access, online-only, continuous publication journal. Copyright

Copyright $\odot 2019$ The Author(s). Published by Wolters Kluwer Health, Inc. on behalf of the American Academy of Neurology.. All rights reserved. Online ISSN: 2332-7812.

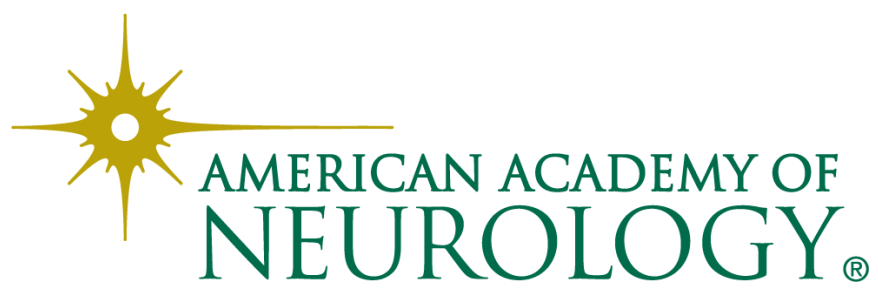

